\author{
KAMILA GIEBA \\ (D) https://orcid.org/0000-0002-6671-7413 \\ Uniwersytet Zielonogórski \\ Zielona Góra
}

\title{
Karykaturalne pogranicze. „Poniemiecja” w tekstach Ziemowita Szczerka
}

\author{
Caricatural borderlands. \\ "Post-German lands" in Ziemowit Szczerek's texts
}

\begin{abstract}
The paper discusses the representation of the so-called Regained Territories in reportage and novels by Ziemowit Szczerek. The aim of the paper is to identify the ways of creating a caricatural imaginary geography of the Polish-German borderlands which Szczerek calls "Poniemiecja" ["Post-German lands"]. An analysis of the source material made it possible to determine the functions of the borderlands theme in Szczerek's works (demythologisation, deheroisation, confrontation). The paper also presents strategies of revising the pioneer myth of the so-called Regained Territories and of representing the Polish-German relations in Szczerek's works of fiction and non-fiction.
\end{abstract}

Key words: borderlands studies, Regained Territories, Polish literature, contemporary literature, Ziemowit Szczerek

Tematem artykułu jest motyw zachodniego pogranicza Polski, obecny w twórczości prozatorskiej Ziemowita Szczerka. Celem szkicu jest określenie, w jaki sposób autor tworzy literacką geografię wyobrażoną tzw. Ziem Odzyskanych, dla której charakterystyczne okazują się ironiczne i karykaturalne przerysowania, służące rewizji mitu pionierskiego. Rewizja ta nie jest dokonywana poprzez logiczną argumentację albo rzeczowa polemikę z wcześniejszymi literackimi narracjami o ziemiach przyłączonych po II wojnie światowej do Polski (z idealizującymi obrazami tych terenów np. w prozie Eugeniusza Paukszty czy Jana Brzozy albo z nurtem prozy małoojczyźnianej zapoczątkowanej przez Pawła Huellego). Szczerek celowo konstruuje karykaturę pogranicza, z premedytacją operując stereotypami i żonglując kon- 
wencjami, nadając swoim tekstom ton ironiczny, a nawet prześmiewczy. Stawiam tezę, że taki sposób prezentacji polsko-niemieckiego pogranicza pełni funkcję demitologizująca, deheroizującą oraz konfrontacyjna, do czego powrócę w końcowej partii artykułu, po dokonaniu egzemplifikacji materiału badawczego. W tym miejscu nadmienię tylko, że te trzy strategie rewizji mitu pionierskiego - demitologizację, deheroizację oraz konfrontacje można odczytać jako odpowiedź na dotychczasowe formuły narracji o tzw. Ziemiach Odzyskanych, które wyczerpują się ze względu na powtarzalność motywów i ich schematyczne wykorzystanie ${ }^{1}$.

W literaturoznawczej i medioznawczej refleksji nad tekstami Szczerka omawiana tutaj problematyka jest raczej pomijana. W namyśle nad jego twórczością eksponowane są głównie dwa inne zagadnienia. Pierwsze z nich dotyczy klasyfikacji genologicznej (reportaż gonzo, „ł̇̇ereportaż”), drugie problematyki narodowościowej i tożsamościowej Europy Środkowej i Wschodniej (a w szczególności Ukrainy). Szczerek jest określany jako pierwszy polski reporter piszący w konwencji gonzo (na ten temat por. m.in.: Adamczewska 2014b, 187-204; Frukacz 2015, 49-61; Szydłowska 2015, 375-387; Żyrek-Horodyska 2017, 217-232). Ta odmiana reportażu ma swoje źródła w amerykańskim Nowym Dziennikarstwie, którego głównym przedstawicielem jest Hunter Stockton Thompson, autor reportażowych tekstów gonzo z lat 70. XX wieku: Upadku i demoralizacji na Derby Kentucky oraz Leku i odrazy w Las Vegas (Adamczewska 2014a, 341). Gatunek ów to reportaż paradokumentalny, w którym dopuszczalne jest stosowanie rozbudowanych elementów fikcyjnych, skrajna subiektywizacja, hiperboliczne i karykaturalne przedstawianie świata oraz uczynienie z reportera centralnej postaci, czyli bohatera, który niejednokrotnie wciela się w role awanturnika i prowokatora.

Takie chwyty zastosował Szczerek przede wszystkim w książce Prayjdzie Mordor i nas zjje, czyli tajna historia Stowian (Szczerek 2013a). Do głównego tematu Mordoru - współczesnych przemian społecznych, kulturowych i politycznych na Ukrainie - powraca w kolejnym reportażu, już mniej zbliżonym do stylistyki gonzo - w Tatuażu z. tryzubem (Szczerek 2015), opowiadającym

1 Te powtarzalne motywy to np. podkreślanie paralelizmu losów wysiedlanych Polaków i Niemców; tzw. Ziemie Odzyskane jako miejsce tranzytowe i anonimowe (wątek członków AK zaczynających na pograniczu nowe życie i ukrywających swoją przeszłość); ponowne odkrywanie przedwojennego dziedzictwa wpisane w metaforę palimpsestu. Przykładami ich zastosowania sa np. powieści: Piekło odzyskane Grzegorza Majewskiego (2015), Wypedzony Jacka Inglota (2012) czy też książki Macieja Paterczyka Na zglisz̧çach (2015) oraz Ziemie niczyje (2014). 
o ukraińskich polityczno-społecznych realiach po Majdanie. Również w swojej najnowszej książkowej publikacji reporterskiej - w Międzymorzu (Szczerek 2017) - pisze o tym państwie, tym razem jednak nie jest to główny temat, bowiem w porównaniu do Mordoru oraz Tatuażu z tryzubem autor znacznie poszerzył spektrum zagadnień, pokazując państwa bałkańskie oraz środkowoi wschodnioeuropejskie przez pryzmat narodowych i etnicznych mitów oraz mocarstwowych aspiracji. Jednak Szczerek to nie tylko reportażysta: wydał także dwie powieści - Siódemke (Szczerek 2014) oraz Siny dym (Szczerek 2018) - oraz alternatywną historię Polski opartą na genologicznej konwencji eseju historycznego, zatytułowaną Rzeczpospolita zwycięska (Szczerek 2013b).

Twórczość Szczerka jest kojarzona bardziej z „Poradziecja”, czyli terytoriami zdekolonizowanymi, które w różnych momentach dziejowych pozostawały pod formalnym i nieformalnym wpływem ZSRR czy Rosji, niż z „Poniemiecją"2: terenami należącymi przed II wojną światową do Niemiec, a przyłączonymi do Polski w 1945 roku. Tymczasem tzw. Ziemie Odzyskane sa stale obecne w reportażowej i fikcjonalnej prozie Szczerka. Autor pisze o nich w sposób karykaturalny, drwiący, groteskowy i przerysowany, dążąc do całkowitej, momentami nawet obrazoburczej demitologizacji dyskursu pionierskiego. Wprawdzie we współczesnej polskiej literaturze podejmowane sa próby rewidowania mitu osadniczego, m.in. w prozie Joanny Bator, Ingi Iwasiów, Macieja Paterczyka, Dominika Rutkowskiego, Olgi Tokarczuk (por. m.in. Iwasiów 2012, 209-224; Mikołajczak 2014, 18-39; Siewior 2013, 266-289), jednak na tle wymienionych autorów Szczerek dokonuje rewizji szczególnie radykalnej i bezkompromisowej. Warto zatem przyjrzeć się bliżej temu elementowi jego twórczości.

Stosunkowo najmniej o zachodnim pograniczu Polski pisze Szczerek w swoich ukraińskich reportażach. Jeśli już o nim wspomina, czyni to w odniesieniu do Ukrainy. Zachodnioukraińskie terytorium porównuje do zachodniopolskiego pogranicza, budując paralelę między migracyjnym doświadczeniem obu narodów. I tu, i tam doszło do przesiedleń; i tu, i tam po wysiedlonej ludności pozostały elementy dawnego krajobrazu kulturowego, takie jak zapomniane, opuszczone cmentarze:

Czasem mijałem stare polskie cmentarzyki, dokładnie takie same jak stare cmentarze niemieckie na Dolnym Śląsku, w Lubuskiem czy na Pomorzu. (...) kruszejące nagrobki z martwymi nazwiskami sterczące pomię-

${ }^{2}$ Oba określenia - Poradziecja i Poniemiecja - to autorskie neologizmy Ziemowita Szczerka. 
dzy dzikimi chaszczami, pomiędzy starymi drzewami. Wydawało się, że już nikt o tych nagrobkach nie pamiętał (Szczerek 2015, 7).

Podobieństwo między ukraińskim i polskim zachodem dotyczy również zawłaszczania terytorium, tworzenia wpisanych w przestrzeń domen symbolicznych - znaków panowania grupy narodowej nad miejscem (Nijakowski 2006, 11). Szczerek opisuje rewitalizowaną kamienicę w ukraińskim Gródku, na której widnieje napis: „Pradziadowie zbudowali, my odnawiamy”. Zestawia ten widok z tzw. Ziemiami Odzyskanymi: „Przypominało mi to trochę tabliczki, które często widuję na polskich ziemiach poniemieckich. Są na nich zaklęcia o piastowskości Kłodzka, odwiecznej polskości Dolnego Śląska czy ziemi lubuskiej" (Szczerek 2015, 91).

Te epizodyczne wzmianki o Ziemiach Zachodnich są w ukraińskich reportażach autora konstruowane na zasadzie paraleli z terytorium zachodniej Ukrainy, nie stanowią natomiast samodzielnego motywu. Znacznie więcej uwagi poświęca Szczerek pograniczu polsko-niemieckiemu w reportażu Miedzymorze. Jest to szczególne miejsce na polskiej mapie: „Przez Poniemiecję dawniej po prostu przejeżdżałem, traktując ją jak każdą inną część Polski. Tyle że poniemiecka. Minęło trochę czasu, zanim zrozumiałem, z jak niesamowitym miejscem mam do czynienia. Kawał Europy, w samym jej środku, w którym dokonano totalnej wymiany ludności" (Szczerek 2017, 12). O charakterze tzw. Ziem Odzyskanych zadecydowały procesy migracyjne, uruchomione po II wojnie światowej, na skutek których nastąpiło kulturowe oswajanie „poniemieckich” ziem. Beata Halicka charakteryzuje ówczesna sytuację geopolityczną w ten sposób: „Mowa tu o regionie w sercu Europy, który po katastrofie drugiej wojny światowej przedstawiał przestrzeń dzika, wyludnioną i zrujnowana. Wojna zmusiła miliony ludzi do migracji. Po jej zakończeniu na terenie Nadodrza nastapiła niemal całkowita wymiana ludności” (Halicka 2015, 11)3. Pomimo że Szczerek przyznaje „Poniemiecji” specjalny, wyjątkowy w skali Polski status miejsca tranzytowego, to jednak daleki jest od mitologizacji. Powojenne przesiedlenia wydają się projektem

\footnotetext{
3 Autorka mianem „Nadodrza” określa nie tylko terytoria położone w okolicach dorzecza Odry. Nadaje temu określeniu szersze, pozageograficzne znaczenie i traktuje je jako nazwę tych terenów, które po II wojnie światowej na mocy konferencji jałtańskiej zostały włączone w granice powojennej Polski. W pracy pisze nie tylko o zachodnim pograniczu Polski, ale także m.in. o Pomorzu czy Warmii i Mazurach. Wpisanie tych terenów w dyskurs „nadodrzański” jest jednak dyskusyjne. Z możliwością zastosowania terminu „Nadodrze” do tych regionów polemizuje Arkadiusz Kalin w recenzji Na drikich polach badawczego zachodu (Kalin 2014/2015).
} 
karkołomnym, wręcz szalonym. Wprawdzie z łatwością można przemieścić ludność fizycznie, ale nie można tak prosto zmienić ich mentalności: „Każdy, kto się spodziewał, że wystarczy przesiedlić ludzi ze wschodniej Europy do zachodnioeuropejskich miasteczek, by od razu stali się zachodnimi Europejczykami, musiał być niespełna rozumu" (Szczerek 2017, 55). Powojenne wysiedlenia i migracje autor traktuje jak kulturowy i socjologiczny eksperyment, w dodatku nie do końca udany. Charakterystyczne dla prozy Szczerka jest pejoratywne zestawianie wschodu i zachodu, ze świadomym wykorzystaniem stereotypowych asocjacji. Zachód jest otwarty, nowoczesny, miejski, wschód - zamknięty, zacofany i wiejski. Pogranicze polsko-niemieckie ze względu na swoje geograficzne usytuowanie powinno wpisać się w ten pierwszy paradygmat. Tymczasem okazuje się, że ludzie ze wschodu przywieźli ze sobą... wschód; że nie poradzili sobie z zachodnioeuropejską mentalnością. Nie potrafili także uporać się z obcym krajobrazem: ani go przyswoić, ani zagospodarować. Podróż po „Poniemiecji” to obserwacja „jak kokosi się tu polskość” (Szczerek 2017, 48). Kokosi się - według autora - niezwykle nieudolnie, ponieważ osadnicy nie są w stanie oswoić miejsca:

Wyobrażam sobie, jak przychodzą tutaj ludzie z tego całego słynnego Wschodu, wwożą swoje toboły do wsi, zajmują dom po domu, a potem gromadzą się wokół takiej baszty czy wieży, biorą pod boki i zastanawiaja, jak toto traktować. Niby ładne, ale jednak niemieckie i bezużyteczne. Bo domy to inna historia: niemieckie, ale się przydaja. A tu - po odrzuceniu użyteczności - pozostaje czysta niemieckość. Ale w końcu machaja ręką i dają spokój (Szczerek 2017, 48).

Przestrzeń pogranicza jest miejscem zderzenia kultury oraz przestrzeni polskiej i niemieckiej. Szczerek w prowokacyjnym tonie zestawia ze soba te dwa kulturowe krajobrazy na zasadzie przejaskrawionego kontrastu. O Frankfurcie nad Odrą sąsiadującym ze Słubicami autor pisze: „Puste trupy okien w opuszczonych blokach z widokiem na Polskę, bo kto może, spieprza stąd na Zachód, aż się kurzy (...), być Niemcem i mieszkać w bloku z widokiem na Polskę to jednak dość mocna perwera. Po to się jest Niemcem, żeby żyć w Niemczech, a nie patrzeć na Polskę" (Szczerek 2017, 45). Niemiec nie chce patrzeć na Polskę, ale za to chce do niej przyjeżdżać na zakupy. Polak, zakompleksiony wobec Niemca, toleruje jego obecność, bo wiąże się ona z ekonomiczną korzyścią: „Całe polskie pogranicze wybrzmiewa litanią do Niemca, odmawiana po niemiecku. Polska błagalna, Polska proszalna, bitte, bitte, bitte, cigateren" (Szczerek 2017, 51). Relacje między Polakami i Niem- 
cami w prozie Szczerka stanowczo odbiegają od małoojczyźnianej wizji pogranicza jako miejsca koegzystencji i wymiany kulturowej, nie wpisują się również w tendencję do archeologicznej pracy pamięci, pozwalającej na odkrywanie wielokulturowej przeszłości miejsca. Nie ma tu najmniejszego śladu polifonii pamięci polegającej na międzykulturowej wymianie w duchu otwartego regionalizmu (Rybicka 2012, 195), nie wybrzmiewa też postulat polsko-niemieckiego, transgranicznego dialogu (Bakiewicz 2017, 54). W najnowszej literaturze dotyczącej przesiedleń „Niemiec zaczyna być traktowany jako szansa dla regionu, jako marka w myśl założenia, że prowincja może stać się ciekawa dla centrum ze względu na swoją egzotykę, traktowana jako ciekawostka etnograficzna" (Mikołajczak 2016, 269). U Szczerka ta szansa sprowadza się wyłącznie do kwestii ekonomicznych.

Polskość „kokosząca się” na pograniczu rzeczywiście przybiera postać „ciekawostki etnograficznej”, polegającej na zderzeniu radykalnie odmiennych dominant krajobrazowych. Dysonans wzbudzają np. drewniane zajazdy w okolicach Bogatyni, imitujące wiejskie chaty: „...tutaj dookoła ruiny poniemieckiej cywilizacji, cokolwiek by mówić, wyrafinowanej, a my tu władujemy się z chłopską chatą i pierogami babuni” (Szczerek 2017, 125). Ruiny, zniszczona cywilizacja, Dziki Zachód, postapokalipsa ${ }^{4}$ - te motywy często organizują reprezentację tzw. Ziem Odzyskanych w tekstach Szczerka. Dzieci bawiące się na ulicach Kłodzka to „potomkowie pionierów polskiego dzikiego zachodu, tylko że tutaj nie było Indian. Była wyrafinowana cywilizacja (...), która pozostawiła tutaj swoje trupy, swoje duchy, demony i ruiny” (Szczerek, b.d., online). Cóż stało się z pozostałościami po owej cywilizacji? Szczerek w felietonie Wandale na gruzach Rzymu, czyli Ruinenwert niezwykle brutalnie, wręcz wulgarnie rozprawia się z mitem pionierskim. Opisuje uliczkę w Wałbrzychu, która dawniej była nastrojowa, „...dopóki Naród Polski, który w imię sprawiedliwości historycznej zajął te rdzennie polskie ziemie, nie zasrał jej i nie zaszczał od bruku po dachy. I teraz nie jest już klimatyczna, tylko jebie w niej jak w niewietrzonym sklepie zoologicznym" (Szczerek, b.d., online). Autor dokonuje kolejnej demitologizacji: polscy osadnicy to raczej tytułowi „Wandalowie” niż pionierzy - ojcowie założyciele, twórcy dziedzictwa przekazywanego kolejnym pokoleniom (Lewandowski 2014, 104). Pionierzy jako bohaterowie zbiorowi literatury o powojennych przesiedleniach to „dynamiczna siła, która modeluje estetyczne i so-

\footnotetext{
${ }^{4}$ Nawiązania do postapokalipsy służą Szczerkowi również do opisu Ukrainy, dla której apokalipsą było uniezależnienie się od Rosji, zob. Dąbrowska 2016.
} 
cjokulturowe oblicze anektowanych przestrzeni, funduje system aksjonormatywny, buduje język władzy i wiedzy" (Szydłowska 2013, 454). Natomiast w tekstach Szczerka ludność napływowa stanowi siłę destrukcyjna, a jeśli jest jednak zdolna do modelowania przestrzeni, to jest to modelowanie wyłącznie antyestetyczne.

Pogranicze polsko-niemieckie zostaje upodobnione do terytorium postapokaliptycznego również w powieści Siódemka. Narrator, podróżujący z Krakowa do Warszawy droga krajową nr 7, snuje rozważania o miejscu Polski w Europie i o tym, jak Polska jest postrzegana przez sąsiednie państwa. Motyw tzw. Ziem Odzyskanych pojawia się w kontekście czeskim. Oto jak prezentuje się Polska z perspektywy Czecha:

Lacińska wersja Rosji, gdzie odległości są ogromne, gdzie pełno zaśnieżonej pustki, gdzie miasta mają finezję i urok rozjeżdżonych garażowisk i gdzie człowiek się psychicznie źle z tego powodu czuje, więc lepiej toto omijać z daleka. Polska zresztą dzieli się na dwie części. Jedna to zachodnia, poniemiecka, która:

1) wygląda jak postapokalipsa rodem z Mad Maxa, bo po ruinach dawnej, wysokiej, niemieckiej cywilizacji chlupią Polaki w kufajkach w wiecznym błocie, którego naniosły swymi wschodnimi buciorami na porząane germańskie bruki,

2) należy się Czechom, którzy by tego wszystkiego tak nie spierdolili, jak te Polaki, co to przylazły na ten zachód ze wschodu, a tak naprawdę powinny tam zostać, na tym wschodzie, bo do wschodu należą, po wschodniemu myślą i po wschodniemu ogarniają, a poza tym Wrocław, Kłodzko i tak dalej to historyczne ziemie czeskie, więc wiadomo (Szczerek 2014, 47).

„Postapokalipsę rodem z Mad Maxa” na polsko-niemieckim pograniczu można odczytać po prostu jako sztafaż, ozdobnik, element obrazowej scenerii. Jednak wydaje się, że w prozie Szczerka motyw ów służy innym celom. Jak zauważa Lech M. Nijakowski w swoim szkicu o postapokalipsie w popkulturze: „Katastrofa (...) doprowadza do trwałej destrukcji i transformacji jakiegoś obszaru, na dobre straconego dla normalnego życia” (Nijakowski 2014, 251). Próby odbudowy świata zniszczonego przez katastrofę nie zawsze skutkują zmianą na lepsze: „Odbudowane na ruinach nowe miasta, będące na pierwszy rzut oka idealnymi społecznościami, okazują się trawionymi zepsuciem ustrojami” (Nijakowski 2011, 265). Nijakowski zaznacza, że postapokalipsie towarzyszy transformacja epistemologiczna, powodująca, że 
stare wzory poznawania świata już się nie sprawdzają, a dawne pojęcia tracą przypisane im znaczenia. W tym świetle postapokaliptyczna „Poniemiecja” zyskuje głębsze konteksty: to teren transmutacji kulturowej i krajobrazowej; miejsce nieznormalizowane, trudne do życia, wymagające skomplikowanej i długotrwałej adaptacji do zmiennych warunków; świat, którego nie można podzielić według jednoznacznej linii zarysowanej między tym, co stare i obce, a tym, co nowe i swoje.

W nieco odmiennych kontekstach tzw. Ziemie Odzyskane funkcjonują w dwóch innych fikcjonalnych tekstach Szczerka: w Rzecsypospolitej zwycięskiej oraz w Sinym dymie. W tym przypadku autor wykorzystuje fikcję i spekulację, za pomocą których kreśli możliwe czy też alternatywne dzieje zachodniego pogranicza Polski. Pierwszy z wymienionych utworów to alternatywna historia Polski - kraju, który we wrześniu 1939 roku z powodzeniem stawił czoła niemieckiej agresji, przez co II wojna światowa właściwie skończyła się, zanim na dobre się rozpoczęła. W rezultacie II Rzeczpospolita przetrwała i sukcesywnie realizowała swoje mocarstwowe plany. Druga książka to wizja przyszłości, w której nie ma jednej Polski, jest natomiast kilka konkurujacych ze sobą Polsk. Inne jest też oblicze kontynentu: Unię Europejską zastapił ponadnarodowy twór zwany Neuropa.

Rzeczpospolita zwycięska nie jest powieścia, nie ma fabuly, którą spajaliby bohaterowie literaccy. To raczej rozważania historiograficzne skonstruowane na podobieństwo eseju historycznego, fikcyjne i spekulacyjne wprawdzie, ale bazujące na logice prawdopodobieństwa. Tego typu historie alternatywne charakteryzuje „większa niż w powieści ścisłość myślenia, wnioskowanie poparte zazwyczaj źródłami historycznymi oraz kładzenie nacisku na prawdopodobieństwo alternatywnych wariantów wydarzeń" (Wąsowicz 2016, 96). Na narrację tego typu składają się założenia kontrfaktyczne, odnoszące się do niezrealizowanych możliwości przebiegu historii (Topolski 1999, 4). Szczerek konstruuje zatem uchronię, odpowiadająca na pytanie: „Co by było, gdyby?”; jest to świat alternatywny opowiadający o przeszłości, która potoczyła się inaczej niż stało się to w rzeczywistości (Lemann 2011, 339).

Jeżeli w fikcyjnej Szczerkowej Rzeczypospolitej wojna się nie zdarzyła, to nie doszło także do przesunięcia granic państwowych. Tereny nazywane dziś Kresami Wschodnimi pozostały w granicach państwa, a tym samym tzw. Ziemie Odzyskane nigdy nie powstały. Szczerek jednak nawiązuje do międzywojennej idei zachodniej i kreśli scenariusz, w którym postulaty Romana Dmowskiego czy Jana Ludwika Popławskiego zostały częściowo urzeczywistnione: ziemie położone wzdłuż Odry i Nysy Łużyckiej trafiaja pod pol- 
skie panowanie. Tereny Niemiec zostają rozbite na landy, które znajdują się pod okupacją innych państw. Zwierzchnictwo nad Prusami Wschodnimi obejmuja Litwa i Polska. Osiedla się tam polska ludność, jednak Szczerek nie nazywa tego procesu akcją osadnicza, ale akcją kolonizacyjna. Kolonizatorzy posługują się wobec skolonizowanych przemocą fizyczną i symboliczną:

Niemieckość była urzędowo tępiona i prześladowana (...). Po miastach maszerowali z pochodniami polscy nacjonaliści (...). Maszerujący wykrzykiwali szowinistyczne hasła, tłukli szyby w niemieckich sklepach, a często z rozpędu i właścicieli, i klientów tych sklepów. Polscy policjanci oglądali w tym czasie czubki własnych trzewików, paznokcie, bądź obserwowali chmury ciagnące po polskim już niebie. Co jakiś czas polska prasa donosiła $z$ udawana obojętnością o wyłowieniu kolejnych ciał z mazurskich jezior. Tak się składało, że ciała te niemal zawsze należały do osób o niemieckich nazwiskach (Szczerek 2013b, 138).

Podobne scenariusze rozgrywały się na Pomorzu i Śląsku, które weszły w skład Generalnego Protektoratu z polską administracją wyższego i średniego szczebla, z częścią kompetencji pozostawionych Niemcom (administracja gminna i sołecka oraz służby porządkowe). „Do czasu - dodawali w myślach Polacy, krzyżując palce za plecami” (Szczerek 2013b, 134). Polak to brutalny kolonizator, a w parze z jego brutalnością idzie także barbarzyństwo: „Polscy koloniści w poniemieckich domach wyrywają kontakty ze ścian, bo nie są w stanie pojąc istoty prądu elektrycznego. Jedźcie do Hanoweru, do Szwabii, do Nadrenii, do Bawarii nawet - ze współczuciem radzili Niemcom alianci” (Szczerek 2013b, 142). Niemcy z czasem zaczęli domagać się autonomii. „A najlepiej zmiany okupanta na bardziej, jak to ujmowali, cywilizowanego" (Szczerek 2013b, 209). Generalny Protektorat okazał się kolosem na glinianych nogach. W rezultacie w tych uchronicznych spekulacjach w latach 50. XX wieku Pomorze i Śląsk uzyskały status państw niepodległych.

Takiej wizji Generalnego Protektoratu można przypisać charakterystyczną dla historii alternatywnych funkcję kompensacyjna, służącą „odreagowaniu narodowych traum” (Wąsowicz 2016, 98). Jednak ironiczny i prześmiewczy ton narracji Szczerka wskazywałby raczej na funkcję rewizyjna, która obejmuje „refleksję nad narodowymi mitami i symbolami” zmuszająca „do namysłu nad sensem przeszłych wydarzeń i wytrącającą ze stereotypowego myślenia na temat przeszłości” (Wąsowicz 2016, 100-101). Historie alternatywne są „rodzajem humanistycznego laboratorium, w którym przeprowa- 
dza się szereg eksperymentów myślowych, zadaje pytania, których nie chce zadawać tradycyjna historia, oraz formułuje odpowiedzi, które często są dla historyków nie do pomyślenia" (Wąsowicz 2016, 102). Do takich myślowych eksperymentów należy jednoznaczne określanie Polaków jako kolonizatorów oraz nakreślenie scenariusza, w którym Niemcy stają się bezbronnymi ofiarami barbarzyńskiej brutalności i bezprawia.

W osobliwej sytuacji znajduje się zachodnie pogranicze również w Sinym dymie. Fikcyjna Polska z przyszłości to kraj narodowy ze stolicami w Krakowie i Warszawie. To zarazem kraj podzielony, złożony z wielu grup dążących do autonomii lub do burzenia narodowego status quo: w obrębie państwa działa anarchistyczny Front Antynarodowy, własną enklawą - Chłopią - zarządzaja chłopi, Małopolskę terroryzują separatyści wiślańscy. Separatystyczne dążenia charakteryzuja także zachód kraju: Pomorze uważa się za Europejską Republikę Pomorską ze stolicami w Gdańsku i Szczecinie, a Śląsk za Europejską Republikę Śląską ze stolicami w Katowicach i we Wrocławiu. Obie republiki - nazwane w powieści „postpolskimi” i określane jako „quasi-państwa” - dążą do uzyskania całkowitej autonomii. Sprawę komplikuje podział Śląska na Górny i Dolny. Ten pierwszy zmierza do wzmocnienia śląskości rozumianej nie jako tożsamość etniczna, ale wręcz narodowa; ten drugi - do oderwania się od Polski i przyłączenia do ponadnarodowej Neuropy:

Górny Śląsk starał się wzmóc w Ślązakach poczucie jak najmocniejszej od Polski odrębności, Dolny - przeciwnie - głosił, że era politycznego znaczenia etnicznych nacji już się skończyła, dlatego oni, dawny zachód Polski, razem z Europejską Republiką Pomorską (...) dążą do politycznej i ekonomicznej integracji z Nową Europa (Szczerek 2018, 192).

Szczerek zwraca więc uwage na niejednolitość etniczną i kulturową tzw. Ziem Odzyskanych, na ich regionalne zróżnicowanie i odmienne aspiracje. W efekcie zachodnie pogranicze Polski przypomina eklektyczną mozaikę skomponowaną z niekompatybilnych elementów.

Jeśli Rzeczpospolita znycieskea jest opowiadająca o przeszłości „uchronią, to Siny dym można nazwać „metachronią” - światem przyszłości, wprawdzie fikcyjnym, ale skonstruowanym na bazie obecnych tendencji rozwojowych. Ów świat, chociaż różny od teraźniejszego, ,jest możliwy i prawdopodobny właśnie dlatego, że przeobrażenia, którym zostaje poddany, są przedłużeniem tendencji istniejących w świecie rzeczywistym" (Eco 2012, 234). Owe współczesne tendencje, które mogły posłużyć Szczerkowi do metachro- 
nicznych przewidywań, to (oczywiście znacznie upraszczając) proeuropejski i liberalny charakter zachodniego pogranicza oraz dążenia do autonomii Górnego Śląska (Szczerek prawdopodobnie nawiązuje do postulatów Ruchu Autonomii Śląska, czyli „wprowadzenia w Rzeczpospolitej silnych, autonomicznych województw, które będąc niezależne finansowo od władzy centralnej, samodzielnie decydowałyby o własnych sprawach"5). Szczerek uwypukla i radykalizuje te dążenia: sprawdza, jak wyglądałoby państwo, w którym postulaty skrajnie proeuropejskie czy izolacjonistyczne zostałyby urzeczywistnione.

Tzw. Ziemie Odzyskane w prozie Szczerka są przerysowane, hiperboliczne: tak krajobraz, jak ludność pogranicza to karykatury, parodie. Należy zaznaczyć, że takie ujęcia są ściśle związane z konwencją dziennikarskiego gonzo charakterystyczną dla tego autora. Jeśli pominie się ów genologiczny kontekst, jego tekstom z łatwością będzie można zarzucić stereotypowość, proste, czarno-białe, a przez to niesprawiedliwe reprezentacje, tak jak czyni to Marcin Tujdowski, polemizujący z cyklem reportaży Szczerka o zachodnim pograniczu, publikowanych na łamach „Polityki”. „Rzeczywistość na polsko-niemieckim pograniczu nie jest tak jednoznaczna, jak w artykułach Szczerka, gdzie role są już rozdane i tymi złymi są wiecznie zacofani i niepoprawnie katoliccy Polacy" - pisze politolog (Tujdowski 2017, 789). Sposób opisywania krajobrazu kulturowego przez Szczerka komentuje następująco: „Polscy mieszkańcy owych ziem jawią się jak wirus, albo lepiej - termity, które podgryzają poniemiecką tkankę architektoniczną i jedyne co potrafia, to wstawianie swoich niezgrabnych termitier do tego obcego dla nich krajobrazu kulturowego" (Tujdowski 2017, 791). Zarzuca autorowi, że ten, jak osoba „z zewnątrz”, nie pojął skomplikowanych procesów oswajania poniemieckiego terytorium. Tujdowski dokonuje jednak analizy z punktu widzenia politologa, traktując teksty Szczerka jako całkowicie referencyjne, pomijając natomiast ich literacki - a zatem dopuszczający stosowanie fikcjiwymiar.

Motyw zachodniego pogranicza Polski w tekstach Szczerka można odczytać jako obrazoburcze igranie z kategoriami narodu i państwa. Istotne jest jednak przy tym uwzględnienie autorskiego idiolektu reportera. Reprezentacje tzw. Ziem Odzyskanych w prozie Szczerka wpisują się w styl autora, który Arkadiusz Kalin nazwał „szczerkowszczyzną” - jej cechy to połączenie

\footnotetext{
${ }^{5}$ Cytuję za informacją podaną na stronie internetowej Ruchu Autonomii Śląska: http:// autonomia.pl/stowarzyszenie-ruch-autonomii-slaska/ [dostęp: 28.03.2019].
} 
erudycji z popkulturowym slangiem, humorystyczny i ironiczny ton, parodystyczna kondensacja stereotypu i (tragi)komiczne scenki rodzajowe (Kalin 2017, online). W efekcie otrzymujemy prześmiewczą wizję tzw. Ziem Odzyskanych. Jej charakter dobrze oddaje metafora krzywego zwierciadła, którą Joanna Szydłowska zastosowała do interpretacji Mordoru: „Ukraińskie peryferie są lustrem, w którym przeglądamy się my sami. A że zwierciadło wypożyczono z gabinetu krzywych luster, to otrzymaliśmy obraz zniekształcony" (Szydłowska 2015, 387). Wydaje się, że opis tzw. Ziem Odzyskanych służy temu samemu celowi, który towarzyszył właśnie Mordorowi:

Ta żonglerka [mitów, stereotypów, elementów tradycji literackiej - K.G.] ma poważny potencjał rebeliancki i emancypacyjny, jest nieodzowna, by przewietrzyć rekwizytornię naszej wyobraźni, by odświeżyć język. Bezczelna kpina z narodowych kompleksów, drwiny z polskiej megalomanii i hipokryzji to rudymenty antybrązowniczego projektu Szczerka (Szydłowska 2015, 389).

Owo odbrązowienie reprezentacji tzw. Ziem Odzyskanych wiąże się z pierwszą funkcją, którą można wyczytać z utworów Szczerka. Jest to funkcja demitologizująca. Wieloletni proces zasiedlania i adaptowania kulturowego pogranicza polsko-niemieckiego obrósł w mit zwany piastowskim (Tumolska 2007, 146), do którego popularyzacji przyczynił się oficjalny dyskurs PRL. W micie tym Polacy powracają na ziemie odwiecznie polskie, zagrabione przez Niemców; powracaja po stuleciach w wyniku działania sprawiedliwości dziejowej. Takie ujęcie było stale reprodukowane we wspieranej przez politykę kulturalna przedtransformacyjnej literaturze osadniczej (w utworach m.in. Haliny Auderskiej, Jana Brzozy, Eugeniusza Paukszty, Jerzego Pytlakowskiego, Leszka Proroka czy Wojciecha Żukrowskiego). Szczerek natomiast opatruje ów proces migracyjny wyrazistymi kontekstami kolonialnymi, które - jak można przypuszczać - służą krytycznej reinterpretacji tużpowojennych dziejów Polski. Demitologizacji towarzyszy funkcja kolejna: deheroizacyjna. Pionierzy zostaja całkowicie odarci z bohaterskich cech, przedstawieni nie jako odnowiciele miejsca, ale jako siła destrukcyjna, bezwzględna i zaślepiona, niszcząca niemieckie dziedzictwo materialne. Zderzenie z tym dziedzictwem kieruje uwagę na następną funkcję, którą nazywam tu roboczo konfrontacyjną. Konfrontacji podlegają dwie przestrzenie kulturowe, które Szczerek nakłada na typy mentalności, wpisane w wyrazistą epistemologiczną opozycję między zachodem i wschodem. Człowiek może zostać przemieszczony geograficznie, ale nie oznacza to jednoczesnego przemieszczenia 
mentalnego. Szczerek uwypukla, wyolbrzymia tę tezę, a jednocześnie w przewrotny sposób zwraca uwagę na niezwykle trudną sytuację przesiedleńców, ludzi podlegających nie tylko geograficznej, ale również kulturowej dyslokacji, zmuszonych do borykania się z przestrzenią, która generuje trudne do przezwyciężenia poczucie obcości.

Szczerek posługuje się przede wszystkim prowokacją. Prowokowaniu służy nonszalancki, niekiedy wulgarny i bezczelny ton, deformujące przerysowanie, szyderstwo i daleko idące uproszczenia. Wydaje się, że właśnie prowokacja stanowi najbardziej radykalne narzędzie demitologizujące. Zmusza do refleksji krytycznej nad procesami migracyjnymi, do ciagłego rewidowania dominujących wzorców opowieści o powojennym polsko-niemieckim pograniczu, o kategoriach kulturowego wchodu i zachodu, o narodowych aspiracjach i kompleksach.

\section{Literatura}

Adamczewska I., 2014a, Gonzo journalism. Materiaty do „Stownika Rodrajón Literackich”, „Zagadnienia Rodzajów Literackich”, t. LVIII, z. 1.

Adamczewska I, 2014b, Wariacje na temat pewnego paktu. O driennikarstwie gonzo, „Czytanie Literatury. Łódzkie Studia Literaturoznawcze”, nr 3.

Bąkiewicz M.J., 2017, Dialektyka luk i wypetnień. Praycaynek do wspótczesnych badań nad krajobrazem kulturowym, w: Bąkiewicz M.J., red., Lubuski palimpsest. W kregu historii, kultury i literatury polsko-niemieckiego pogranicza, Zielona Góra.

Dąbrowska J., 2016, Obraz państwa postapokaliptycznego w prozie Ziemowita Sžrzerka, „Annales Universitatis Mariae Curie-Skłodowska", vol. XXXIV, nr 2.

Eco U., 2012, Światy science-fiction, w: Eco U., Po drugiej stronie lustra $i$ inne eseje, przel. Wajs J., Warszawa.

Frukacz K., 2015, Amerykańskie Nowe Dziennikarstwo po polsku? Transfer poetyk, problemy adaptacyjne, w: Hajduk-Gawron W., red., Adaptacje II. Transfery kulturowe (Biblioteka Postscriptum Polonistycznego, t. V), Katowice.

Halicka B., 2015, Polski Driki Zachód. Przymusowe migracje i kulturowe oswajanie Nadodrza 1945 1948, przel. Łuczak A., Kraków.

Iwasiów I., 2012, Hipoteza powieści neo-post-osiedleńczej, w: Gosk H., red., Narracje migracyjne w literaturze polskiej XX i XXI wieku, Kraków.

Kalin A., 2014/2015, Na drikich polach badawczego zachodu, „Literaturoznawstwo”, nr 8/9.

Kalin A., 2017, Mięsy Rurytania a Borduria czyli smutek snów o potęze, „Czas Kultury” 19.06.2017, http://czaskultury.pl/czytanki/miedzy-rurytania-a-borduria-czyli-smuteksnowo-potedze/ [dostęp: 14.09.2918].

Lemann N., 2011, Cay można uchronić się od przeszłości? Historie alternatymne i uchronie jako literackie aporie polityki i wiedzy historycznej, „Zagadnienia Rodzajów Literackich”, t. LIV, z. 2. 
Lewandowski P., 2014, Model narracji o pionierach. Studium nad podobieństwami pamięci zbiorowej, „Teksty Drugie”, nr 5.

Mikołajczak M., 2014, Choroba migrantów - literacka epikryza i patogenez̧a (na prazyktadzie literatury osadniczej i postosadniczej), „Teksty Drugie”, nr 6.

Mikołajczak M., 2016, Do czego literaturze regionalnej potrzebny jest Niemiec? (na praykeładzie twórczości lubuskiej), ,Teksty Drugie”, nr 3.

Nijakowski L.M., 2006, Domeny symboliçne. Konflikty narodowe $i$ etniczne w wymiarze symbolicznym, Warszawa.

Nijakowski L.M., 2011, Popularne postapokalipsy późnej nowoczesności, „Colloquia Anthropologica et Communicativia", nr 3.

Ruch Autonomii Śląska, strona internetowa: http://autonomia.pl/stowarzyszenie-ruch-auto nomii-slaska/ [dostęp: 28.03.2019].

Rybicka E., 2012, Czy możliwa jest „polifonia pamięi” w literackich badaniach regionalnych? Na prayk.tadzie pogranicza polsko-niemieckiego, w: Mikołajczak M., Rybicka E., red., Nowy regionalizm w badaniach literackich: badawczy rekonesans $i$ zarys perspektyw, Kraków.

Siewior K., 2013, Tożsamość odsyskana? (Re)transkrypcje doświadczenia migracyjnego w powieści neo-post-osiedleńczej, „Teksty Drugie”, nr 3.

Szczerek Z., 2013a, Przyjdziie Mordor i nas zje, czyli tajna bistoria Stowian, Kraków.

Szczerek Z., 2013b, Rzeczpospolita zuycięska. Alternatywna historia Polski, Kraków.

Szczerek Z., 2014, Siódemka, Kraków.

Szczerek Z., 2018, Siny dym albo piéć cywilizowanych plemion, Wołowiec.

Szczerek Z., 2015, Tatuaż z tryzubem, Wołowiec.

Szczerek Z., 2017, Międzymoræe. Podróże præez prawdziwa i wyobrażona Europe Środkowa, Wołowiec-Warszawa.

Szczerek Z., (b.r.), W andalowie na gruzach Rzymu, çyli Ruinenwert, strona internetowa Korporacji Halart, dział „Felietony”, http://www.ha.art.pl/felietony/2744-ziemowit-szczerek-wanda lowie-na-gruzach-rzymu-czyli-ruinenwert.html [dostęp: 9.09.2018].

Szydłowska J., 2013, Narracje pojałtańskiego Okcydentu. Literatura polska wobec pogranicza na prayketadzie Warmii i Mazur (1945-1989), Olsztyn.

Szydłowska J., 2015, O pożytkach z.podgladania marginesu, czyli po co centrum peryferie. Egzotyzacja swiata w prozie reportaz̧owej Ziemowita Szczerka (Prayjdzie Mordor i nas zje, czyli tajna historia Stowian), w: Browarny W., Lisak-Gębala D., red., Centra - peryferie w literaturže polskiej XX $i$ XXI wieku, Kraków.

Topolski J., 1999, Refleksje na temat bistorii alternatywnej, „Przegląd Humanistyczny”, nr 2/3.

Tujdowski M., 2017, Polemika z cyklem reportaży Ziemowita Szczerka („Polityka”, nr 27-29, 31-34, 2014), „Rocznik Ziem Zachodnich”, nr 1.

Tumolska H., 2007, Mitologia Kresów Zachodnich w pamietnikarstwie i beletrystyce polskiej (19452000). Szkice do dziejón kultury pogranicza, Toruń.

Wąsowicz M., 2016, Historie alternatywne w literaturze polskiej: typologia, tematyka, funkcje, „Zagadnienia Rodzajów Literackich", t. LIX, z. 2.

Żyrek-Horodyska E., 2017, Od amerykańskiego snu Thompsona po ukrainski Mordor Szczerka. Estetyzacja świata w duchu gon₹o, „Konteksty Kultury”, nr 14, z. 2. 